\title{
Self-perception and malocclusion and their relation to oral appearance and function
}

\author{
Auto-percepção e má oclusão \\ relacionadas à aparência e a função bucal.
}

\author{
Sílvia H elena de Carvalho Sales Peres ${ }^{1}$ \\ Suzana Goya ${ }^{1}$ \\ KarineLaura Cortellazzi ${ }^{2}$ \\ Gláucia M aria Bovi Ambrosano 2 \\ $M$ arcelo de Castro M eneghim ${ }^{2}$ \\ Antonio Carlos Pereira ${ }^{2}$
}

\footnotetext{
${ }^{1}$ Departamento de

Odontopediatria Ortodontia eSaúde Coletiva, Universidade deSão Paulo. Alameda O ctávio Pinheiro Brisola 9-75, Vila Universitária. 17012-101 Bauru SP. shcperes@usp.br ${ }^{2}$ Faculdade de O dontologia dePiracicaba, Universidade deCampinas
}

Abstract The aim of this study was to evaluate the relationship between malocdusion and selfperception of oral appearance/function, in 12/15year-old Brazilian adolescents. The cluster sample consisted of 717 teenagers attending 24 urban public $(n=611)$ and 5 rural public $(n=107)$ schools in M aringá/PR. M alocclusion was measured using the Dental A esthetic Index (DAI), in accordance with WHO recommendations. A parental questionnaire was applied to collect information on esthetic perception level and oral variables related to oral health. U nivariate and multiple logistic regression analyses were performed. M ultiple logistic regression confirmed that for 12-yearold, missing teeth $(O R=2.865)$ and presence of openbite (open occlusal relationship) $(O R=2.865)$ were risk indicators for speech capability. With regard to 15-year-old, presence of mandibular overjet (horizontal overlap) ( $O R=4.016)$ was a risk indicator for speech capability and molar relationship ( $O R=1.661$ ) was a risk indicator for chewing capability. The impact of malocdusion on adolescents' life was confirmed in this study. Speech and chewing capability were associated with orthodontic deviations, which should be taken into consideration in oral health planning, to identify risk groups and improve community health services.

Key words Malocclusion, Adolescent health, Self concept, O ral health
Resumo Este estudo objetivou avaliar a relação entre a má oclusão e a autopercepção da aparência/função bucal em adolescentes brasileiros de 12/15 anos de idade. A amostragem foi probabilística, constituída por 717 adolescentes de escolas públicas, sendo 24 urbanas $(n=611)$ e 5 rurais ( $n=107)$, em M aringá/PR. A má oclusão foi medida por meio do Índice deEstética Dental (DAI), de acordo com os critérios da OM S. Foi aplicado um questionário aos pais para coletar informações sobre o nível de percepção estética e as variáveis relacionadas à saúde bucal. Análises univariada e de regressão logística múltipla foram realizadas. A regressão logística múltipla confirmou que para 12 anos, os dentes ausentes ( $O R=2,865)$ e a presença de mordida aberta $(O R=2,865)$ foram indicadores de risco na capacidade de fala. Com relação aos 15 anos, a presença de overjet mandibular $(O R=4,016)$ foi um indicador derisco para a capacidade de expressão ea relação molar ( $O R=1,661)$ foi um indicador de risco para a capacidade mastigatória. 0 impacto da má oclusão na vida dos adolescentes foi confirmado neste estudo. A capacidade da fala e da mastigação esteve associada às alterações ortodônticas, as quais devem ser levadas em consideração no planejamento de saúde bucal, para identificar grupos de risco e para melhorar os serviços de saúde.

Palavras-chave Má oclusão, Saúdedo adolescente, Autoimagem, Saúde bucal 


\section{Introduction}

It has been reported that clinical (normative) and subjective (self-assessment) evaluation of malocclusion demonstratea significant disparity. The dental public health team is obliged to recognize and understand this gap.

Esthetic perception variesfrom person to person and isinfluenced by their personal experience and social environment. For this reason, professional opinions regarding evaluation of facial esthetics may not coincidewith the perceptions and expectations of patients or lay people $e^{1,2}$.

Theanterior visibleocclusion and examiner's level of education may be important for understanding the patient's perception when discussing the esthetic considerations of orthodontic treatment ${ }^{3}$.

An important motivational factor is to improvedentofacial appearance $e^{4,5}$. The relationship between physical appearance and perception of an esthetic deviation, and the impact of such a deviation on self-esteem and body image is an important issue in determining the benefits of orthodontic treatment.

A variety of social, cultural and psychological factors, and personal norms influence the perception of physical attractiveness ${ }^{6,7}$. Studies in social psychology indicate that physical attractiveness plays a major role in social interaction and influences the impression of an individual's social skill7,8.

TheD ental Aesthetic Index (DAI) adopted by the World Health Organization has been used to assess malocclusion and determine treatment needs ${ }^{9-11}$, and has been integrated into all items of the International Collaboration Study of O ral $\mathrm{H}$ ealth outcomes and guidelines by the W $\mathrm{HO}^{12,13}$. Self or patient opinions regarding orthodontic treatment needs have previously been recorded for dental and facial appearance $e^{6,14,15}$, and such concerns do not always concur with professional evaluations of treatment requirements ${ }^{16,17}$.

The aim of this study was to evaluate the re lationship between the dental aesthetic index (DAI) and self-perception of oral appearanceand function in 12/15-year-old Brazilian adolescents.

Materials and method

Ethical aspects

Thestudy was approved by the Research Ethics Committee of the Bauru Dental School, Uni- versity of São Paulo. Written permission was obtained from adolescents' parents before starting the clinical examinations.

\section{Sample}

In total, a cluster sample composed of 717 students, aged 12 and 15 years, attending 30 representative public schools in M aringá, Brazil, were examined. The sample was organized by gender ( 340 girls, 377 boys) and age ( 402 - 12-year-olds, 315 - 15-year-olds). The clusters were rural $(n=212)$ and urban $(n=1192)$ schools. Schools and grades were randomly selected.

The cluster sampling method was used admitting a sampling error of $5 \%$, mean dmft of 2.5 with standard deviation of 1.8, a confidence level of $95 \%$ and loss of $20 \%$.

Students who had orthodontic treatment or werecurrently wearing an orthodontic appliance were not included in the study.

\section{Examination methodology}

Clinical examination was performed by one previously calibrated examiner, outdoors, under natural light, using CPI probes ("ball point"), mirrors $\# 5^{13}$ and air-drying. Before examination each children performed tooth brushing supervised by a dental hygienist.

\section{Calibration}

A benchmark dental examiner ("Gold Standard"), experienced in epidemiological surveys, conducted the calibration process that lasted 24 hours ( 4 sessions). Theoretical and practical activities with discussions on the diagnostic criteria of malocclusion were performed by two examiners (gold standard and main examiner). A pproximately $10 \%$ of the sample was re examined in order to verify theintra-examiner reproducibility. Inter-examiner agreement was 0.85 expressed by the Kappa statistics. This value indicated reliability within acceptable limits ${ }^{18}$.

\section{Diagnostic criteria and codes}

Professional treatment needs were obtained by assessing the teenagers using the DAI in accordance with the WHO guideline ${ }^{13}$. All 10 components of the index were assessed (Table 1). One of the authors was previously calibrated using re-examination of dental students. 
Table 1. The standard DAI regression equation.

\begin{tabular}{lc}
\hline \multicolumn{1}{c}{ DAl Components } & Weight \\
\hline $\begin{array}{l}\text { 1. Number of missing visible teeth (incisors, canines and premolars teeth in maxillary and } \\
\text { mandibular arches). }\end{array}$ & 6 \\
2. Crowding in the incisal segment ( $0=$ no segment crowded; $1=1$ segment crowded; $2=2$ & 1 \\
segments crowded). & 1 \\
3. Spacing in the incisal segment ( $0=$ no spacing; $1=1$ segment spaced; $2=2$ segment & 1 \\
spaced). & 1 \\
4. Midline diastema in millimeters. & 2 \\
5. Largest anterior irregularity on the maxilla in millimeters. & 4 \\
6. Anterior maxillary overjet in millimeters. & 4 \\
7. Anterior mandibular overjet in millimeters. & 3 \\
8. Vertical anterior openbite in millimetrs. & 13 \\
9. Anterior-posterior molar relation (largest deviation from normal either left or right): \\
0=normal; $1=1 / 2$ cusp either mesial or distal; $2=0$ one full cusp or more either mesial or distal. \\
10. Constant. & DAl score \\
Total &
\end{tabular}

WHO, 1997.

\section{Questionnaire}

All teenagers received a semi-structured questionnaire to be answered according to their selfperceptions and perceived esthetic of malocclusion. Thegoal of this questionnairewas to collect information about speech capability, chewing capability and report of pain.

\section{Data Analyses}

Univariate analyses using the $\mathrm{Chi}$-square test $\left(\chi^{2}\right)$ at $5 \%$ significance level were performed to test theinfluence of independent variables (openbite, missing teeth, crowding, spacing, midline diastema, maxillary irregularity, mandibular irregularity, maxillary overjet, mandibular overjet, molar relation and gender on dependent variables (speech capability, chewing capability and report of pain). The dependent variables (speech and chewing capability) were dichotomized into $\mathrm{bad} / \mathrm{regular}$ and good/excellent while the dependent variable "report of pain" was dichotomized into children with or without pain. Theindependent variables related to DAI components (Table 1) were dichotomized according to absence (code 0 ) and presence (code 1). Next, multiple logistic regression analyses using the stepwise procedure were performed in order to identify the self-perception indicators. In order to eliminatevariables that would makelittlecontribution to themodel, only the independent variables that showed significant association at $p \leq 0.15$ in the univariate analysis were tested in regression model 19,20 . The logistic regression models were adjusted estimat- ing the O dds Ratios (OR), their $95 \%$ confidence intervals (IC), and significancelevels. All statistical analyses were performed using the SAS software ${ }^{21}$ at $5 \%$ significance level.

\section{Results}

The Dental Aesthetic Index (DAI) was calculated using the scores expressed in Table 1.

Tables 2, 3 and 4 present univariate analyses, using Chi-square or the Fisher's Exact Test, associating dependent variables (speech capability, chewing capability and report of pain) with independent variables cited in DAI classification (Table1).

Table 2 shows the statistically significant association (all variables at $p<0.15$ were tested in regression analysis) between "speech capability" and openbite, missing teeth and spacing for 12year-olds, while for 15-year-old sample "speech capability" was associated with maxillary irregularity, mandibular overjet and molar relationship.

In Table 3 a statistically significant association between "chewing capability" and mandibular irregularity can be found for 12 year olds, as well as openbite, maxillary overjet and molar relationship for 15-year-olds.

"Report of pain" was statistically associated with missing teeth and mandibular irregularity for 12-year-olds, as well as mandibular overjet and gender for 15 year olds (Table 4).

The data from the regression analyses confirmed most of these associations. For the $12-$ year-old sample, missing teeth $(\mathrm{OR}=2.865)$ and presence of openbite $(\mathrm{OR}=2.865)$ were risk indi- 
Table 2. Univariate analyses of the association between "speech capability" (dichotomization in bad/regular and good/ excellent) and malocclusion in 12-15 year-old adolescents.

\begin{tabular}{|c|c|c|c|c|c|c|c|}
\hline \multirow[b]{3}{*}{$\begin{array}{c}\text { Independent } \\
\text { variables }\end{array}$} & \multirow[b]{3}{*}{$\begin{array}{l}\text { Absence (0), } \\
\text { presence (1) }\end{array}$} & \multicolumn{6}{|c|}{ Dependent variable (Speech capability) } \\
\hline & & \multicolumn{3}{|c|}{12 years } & \multicolumn{3}{|c|}{15 years } \\
\hline & & $\begin{array}{c}\text { bad, regular } \\
n(\%)\end{array}$ & $\begin{array}{c}\text { good, excellent } \\
n(\%)\end{array}$ & $\mathrm{p}$ & $\begin{array}{c}\text { bad, regular } \\
n(\%)\end{array}$ & $\begin{array}{c}\text { good, excellent } \\
n(\%)\end{array}$ & $\mathrm{p}$ \\
\hline \multirow[t]{2}{*}{ Openbite } & 0 & $70(19.77)$ & $284(80.23)$ & 0.0578 & $48(18.05)$ & $218(81.95)$ & 0.3413 \\
\hline & 1 & $6(40.00)$ & $9(60.00)$ & & $8(25.00)$ & $24(75.00)$ & \\
\hline \multirow[t]{2}{*}{ M issing teeth } & 0 & $70(19.77)$ & $284(80.23)$ & 0.0578 & $54(18.62)$ & $236(81.38)$ & 0.6486 \\
\hline & 1 & $6(40.00)$ & $9(60.00)$ & & $2(25.00)$ & $6(75.00)$ & \\
\hline \multirow[t]{2}{*}{ Crowding } & 0 & $57(20.14)$ & $226(79.86)$ & 0.6951 & $21(15.79)$ & $112(84.21)$ & 0.2336 \\
\hline & 1 & $19(22.09)$ & $67(77.91)$ & & $35(21.21)$ & $130(78.79)$ & \\
\hline \multirow[t]{2}{*}{ Spacing } & 0 & $50(18.66)$ & $218(81.34)$ & 0.1334 & $48(20.00)$ & $192(80.00)$ & 0.2775 \\
\hline & 1 & $26(25.74)$ & $75(74.26)$ & & 8 (13.79) & $50(86.21)$ & \\
\hline \multirow[t]{2}{*}{ Midline diastema } & 0 & $56(19.86)$ & $226(80.14)$ & 0.5279 & $45(19.40)$ & $187(80.60)$ & 0.6164 \\
\hline & 1 & $20(22.99)$ & 67 (77.01) & & $11(16.67)$ & 55 (83.33) & \\
\hline \multirow[t]{2}{*}{ M axillary irregularity } & 0 & 51 (19.03) & $217(80.97)$ & 0.2255 & $37(16.52)$ & $187(83.48)$ & 0.0804 \\
\hline & 1 & $25(24.75)$ & 76 (75.25) & & $19(25.68)$ & $55(74.32)$ & \\
\hline \multirow[t]{2}{*}{ M andibular irregularity } & 0 & $54(20.38)$ & $211(79.62)$ & 0.8682 & 49 (18.77) & $212(81.23)$ & 0.9831 \\
\hline & 1 & $22(21.15)$ & $82(78.85)$ & & 7 (18.92) & 30 (81.08) & \\
\hline \multirow[t]{2}{*}{ Maxillary overjet } & 0 & $8(25.81)$ & $23(74.19)$ & 0.4535 & $37(18.50)$ & $163(81.50)$ & 0.8538 \\
\hline & 1 & $68(20.12)$ & $270(79.88)$ & & 19 (19.39) & 79 (80.61) & \\
\hline \multirow[t]{2}{*}{ Mandibular overjet } & 0 & $76(20.94)$ & $287(79.06)$ & 0.2085 & $12(28.57)$ & $30(71.43)$ & 0.0800 \\
\hline & 1 & $0(0.00)$ & $6(100.00)$ & & $44(17.19)$ & $212(82.81)$ & \\
\hline \multirow[t]{2}{*}{ Molar relationship } & 0 & 41 (21.13) & $153(78.87)$ & 0.7879 & $53(18.15)$ & $239(81.85)$ & 0.0481 \\
\hline & 1 & $35(20.00)$ & $140(80.00)$ & & $3(50.00)$ & $3(50.00)$ & \\
\hline \multirow[t]{2}{*}{ Gender } & 1 & $37(20.33)$ & 39 (20.86) & 0.9006 & $32(18.60)$ & $140(81.40)$ & 0.9230 \\
\hline & 2 & $145(79.67)$ & $148(79.14)$ & & 24 (19.05) & $102(80.95)$ & \\
\hline
\end{tabular}

cators for "speech capability". As regards the 15year-old sample, presence of mandibular overjet $(\mathrm{OR}=4.016)$ was a risk indicator for "speech capability" and molar relationship ( $\mathrm{OR}=1.661$ ) was a risk indicator for "chewing capability" (Tables 5 and 6).

\section{Discussion}

Botazzo ${ }^{22}$ presents how the problems arising from the concept of collective buccal health are seen as having the same nature and can only be faced using analytical categories from collective health or the social theory of health. Concern over appearanceand dental attractiveness appears to be affected by gender, social class and age $e^{23,24}$. The place of esthetic and functional criteria in determining orthodontic treatment need cannot beunderestimated, as thesearemajor indications for patients seeking orthodontic services.

Due to the increasing global demand for orthodontic care, there is a need to develop meth- ods to assess and grade malocclusion in order to prioritize treatment, particularly for publicly funded programs ${ }^{25}$.

Deviant occlusal traits are relatively easy to use, are identified by DAI, and link clinical and esthetic components mathematically to produce a single score ${ }^{11}$. The structure of the DAI consists of 10 prominent traits of malocclusion, weighted on the basis of their relative importance according to a panel of lay judges.

The DAI combines physical and esthetic aspects of occlusion, including patient perceptions. The DAI equation loses some precision when re gression coefficients are rounded, but this small sacrifice in precision is offset by convenience in many clinical and research application $\mathrm{s}^{26}$. M oreover, its acceptance by the WHO as index will encourage international comparisons.

Epidemiological data concerning occlusal conditions have been accumulated by theW $\mathrm{HO}$ from all over the world using the DAI. The DAI is becoming a common standard for evaluating malocclusion, and WHO has recognized it as a cross- 
Table 3. Univariate analyses of the association between "chewing capability" (dichotomization in bad/regular and good/ excellent) and malocclusion in 12-15 year-old adolescents.

\begin{tabular}{|c|c|c|c|c|c|c|c|}
\hline \multirow[b]{3}{*}{$\begin{array}{c}\text { Independent } \\
\text { variables }\end{array}$} & \multicolumn{7}{|c|}{ Dependent variable (Chewing capability) } \\
\hline & \multirow[b]{2}{*}{$\begin{array}{l}\text { Absence (0), } \\
\text { presence (1) }\end{array}$} & \multicolumn{3}{|c|}{12 years } & \multicolumn{3}{|c|}{15 years } \\
\hline & & $\begin{array}{c}\text { bad, regular } \\
n(\%)\end{array}$ & $\begin{array}{c}\text { good, excellent } \\
\mathrm{n}(\%)\end{array}$ & $\mathrm{p}$ & $\begin{array}{c}\text { bad, regular } \\
n(\%)\end{array}$ & $\begin{array}{c}\text { good, excellent } \\
n(\%)\end{array}$ & $\mathrm{p}$ \\
\hline \multirow[t]{2}{*}{ Openbite } & 0 & $337(95.20)$ & $17(4.80)$ & 0.3849 & $73(27.44)$ & $193(72.56)$ & 0.1200 \\
\hline & 1 & $15(100.00)$ & $0(0.00)$ & & $13(40.63)$ & 19 (59.38) & \\
\hline \multirow[t]{2}{*}{ M issing teeth } & 0 & $337(95.20)$ & $17(4.80)$ & 0.3849 & $84(28.97)$ & $206(71.03)$ & 0.8071 \\
\hline & 1 & $15(100.00)$ & $0(0.00)$ & & $2(25.00)$ & $6(75.00)$ & \\
\hline \multirow[t]{2}{*}{ Crowding } & 0 & $271(95.76)$ & $12(4.24)$ & 0.5421 & $70(29.17)$ & $170(70.83)$ & 0.8116 \\
\hline & 1 & 81 (94.19) & $5(5.81)$ & & $16(27.59)$ & $42(72.41)$ & \\
\hline \multirow[t]{2}{*}{ Spacing } & 0 & $256(95.52)$ & $12(4.48)$ & 0.8468 & $63(27.16)$ & 169 (72.84) & 0.2236 \\
\hline & 1 & 96 (95.05) & $5(4.95)$ & & $23(34.85)$ & 43 (65.15) & \\
\hline \multirow[t]{2}{*}{ Midline diastema } & 0 & 269 (95.39) & $13(4.61)$ & 0.9962 & $75(28.74)$ & $186(71.26)$ & 0.9006 \\
\hline & 1 & $83(95.40)$ & $4(4.60)$ & & $11(29.73)$ & $26(70.27)$ & \\
\hline \multirow[t]{2}{*}{ M axillary irregularity } & 0 & $255(95.15)$ & $13(4.85)$ & 0.7160 & $65(29.02)$ & 159 (70.98) & 0.9162 \\
\hline & 1 & 97 (96.04) & 4 (3.96) & & $21(28.38)$ & 53 (71.62) & \\
\hline \multirow[t]{2}{*}{$\mathrm{M}$ andibular irregularity } & 0 & $250(94.34)$ & $15(5.66)$ & 0.1234 & $61(30.50)$ & $139(69.50)$ & 0.3718 \\
\hline & 1 & $102(98.08)$ & $2(1.92)$ & & $25(25.51)$ & 73 (74.49) & \\
\hline \multirow[t]{2}{*}{ Maxillary overjet } & 0 & $29(93.55)$ & $2(6.45)$ & 0.6087 & $17(40.48)$ & $25(59.52)$ & 0.0730 \\
\hline & 1 & $323(95.56)$ & $15(4.44)$ & & 69 (26.95) & 187 (73.05) & \\
\hline \multirow[t]{2}{*}{ Mandibular overjet } & 0 & $346(95.32)$ & $17(4.68)$ & 0.5873 & $83(28.42)$ & 209 (71.58) & 0.2483 \\
\hline & 1 & $6(100.00)$ & $0(0.00)$ & & $3(50.00)$ & $3(50.00)$ & \\
\hline \multirow[t]{2}{*}{ Molar relationship } & 0 & $187(96.39)$ & 7 (3.61) & 0.3352 & $42(24.42)$ & $130(75.58)$ & 0.0481 \\
\hline & 1 & 165 (94.29) & $10(5.71)$ & & $44(34.92)$ & 82 (65.08) & \\
\hline \multirow[t]{2}{*}{ Gender } & 1 & 171 (93.96) & 11 (6.04) & 0.1940 & $42(31.58)$ & 91 (68.42) & 0.3522 \\
\hline & 2 & $181(96.79)$ & $6(3.21)$ & & $44(26.67)$ & $121(73.33)$ & \\
\hline
\end{tabular}

cultural international index. Katoh et al. ${ }^{27}$ confirmed that Japanese and Native Americans showed significantly poorer dental esthetics than found in American white populations ${ }^{9,28}$. The present study did not consider the samplein relation to nationalities or ethnic origins. However, average $20.0 \%$ of adolescents had no abnormality or minor malocclusion requiring no or slight orthodontic treatment need. Theresults of the present study were no correlation with thestudies by Brazilian Oral Health Survey-2002-200329 (58.1\%) and Frazão et al ${ }^{30}$ in São Paulo (71.3\%) and Marques et $\mathrm{al}^{31}$ in Belo H orizonte (62.0\%). The differences may have occurred through the methods of sample selection and the criteria used for diagnosis. A point to be considering is miscegenation existing in southern region, which may in some way have contributed to the occurrence of a lower prevalence of malocclusion in M aringá-PR.

The reasons for improved self-image are probably the result of age-related conditions ${ }^{32}$, rather than the effects of orthodontic treatment. The pattern of no change in self-esteem corroborates the finding in another study ${ }^{33}$. Orthodon- tic treatment may enhance body image, and particularly facial image ${ }^{34}$. The results of this study showed that gender did not significantly influence an adolescent's orthodontic esthetic self-perception in 12- and 15-year-old people (Tables 2, 3 and 4), however, malocclusion measured by DAI, can strongly influence the perception of esthetic appearance.

In this study, a statistically significant relationship between self-perceived malocclusion and oral appearance/function in adolescents was verified. M issing teeth, openbite presence, mandibular overjet and molar relationship were risk indicators to speech and chewing capability. These findings indicate that the DAI can identify deviant occlusal traits, which suggests that community programs involving orthodontic treatment should take it into consideration during trials.

The association between a subject's perceptions of malocclusion and the DAI score was weak but significant in some variables. M olar relationship discrepancy was the only variable associated with poorer conditions of chewing capability, which supports the findings of Onyeaso and 
Table 4. Univariate analyses of the association between report of pain (dichotomization in without and with) and malocclusion in 12-15 year-old adolescents.

\begin{tabular}{|c|c|c|c|c|c|c|c|}
\hline \multirow[b]{3}{*}{$\begin{array}{c}\text { Independent } \\
\text { variables }\end{array}$} & \multirow[b]{3}{*}{$\begin{array}{l}\text { Absence (0), } \\
\text { presence (1) }\end{array}$} & \multicolumn{5}{|c|}{ Dependent Variable(report of pain) } & \multirow[b]{3}{*}{$p$} \\
\hline & & \multicolumn{3}{|c|}{12 years } & \multicolumn{2}{|r|}{15 years } & \\
\hline & & $\begin{array}{c}\text { without } \\
n(\%)\end{array}$ & $\begin{array}{l}\text { with } \\
\mathrm{n}(\%)\end{array}$ & $p$ & $\begin{array}{c}\text { without } \\
n(\%)\end{array}$ & $\begin{array}{l}\text { with } \\
\mathrm{n}(\%)\end{array}$ & \\
\hline \multirow[t]{2}{*}{ Openbite } & 0 & $226(63.84)$ & $128(36.16)$ & 0.2002 & $178(66.92)$ & $88(33.08)$ & 0.2295 \\
\hline & 1 & $12(80.00)$ & $3(20.00)$ & & $18(56.25)$ & $14(43.75)$ & \\
\hline \multirow[t]{2}{*}{ M issing teeth } & 0 & $231(65.25)$ & $123(34.75)$ & 0.1406 & $190(65.52)$ & $100(34.48)$ & 0.5771 \\
\hline & 1 & $7(46.67)$ & $8(53.33)$ & & $6(75.00)$ & $2(25.00)$ & \\
\hline \multirow[t]{2}{*}{ Crowding } & 0 & $181(63.96)$ & $102(36.04)$ & 0.6936 & $161(67.08)$ & 79 (32.92) & 0.3317 \\
\hline & 1 & $57(66.28)$ & $29(33.72)$ & & $35(60.34)$ & $23(39.66)$ & \\
\hline \multirow[t]{2}{*}{ Spacing } & 0 & $176(65.67)$ & $92(34.33)$ & 0.4431 & $150(64.66)$ & $82(35.34)$ & 0.4462 \\
\hline & 1 & 62 (61.39) & $39(38.61)$ & & $46(69.70)$ & $20(30.30)$ & \\
\hline \multirow[t]{2}{*}{ Midline diastema } & 0 & $183(64.89)$ & 99 (35.11) & 0.7753 & $169(64.75)$ & $92(35.25)$ & 0.3239 \\
\hline & 1 & $55(63.22)$ & $32(36.78)$ & & $27(72.97)$ & $10(27.03)$ & \\
\hline \multirow[t]{2}{*}{ M axillary irregularity } & 0 & $170(63.43)$ & $98(36.57)$ & 0.9848 & $150(66.96)$ & $74(33.04)$ & 0.4503 \\
\hline & 1 & $68(67.33)$ & 33 (32.67) & & $46(62.16)$ & $28(37.84)$ & \\
\hline \multirow[t]{2}{*}{ M andibular irregularity } & 0 & $171(64.53)$ & $94(35.47)$ & 0.0185 & $129(64.50)$ & $71(35.50)$ & 0.5086 \\
\hline & 1 & $67(64.42)$ & $37(35.58)$ & & 67 (68.37) & $31(31.63)$ & \\
\hline \multirow[t]{2}{*}{ Maxillary overjet } & 0 & $26(83.87)$ & $5(16.13)$ & 0.3310 & $25(59.52)$ & $17(40.48)$ & 0.3572 \\
\hline & 1 & $212(62.72)$ & $126(37.28)$ & & $171(66.80)$ & $85(33.20)$ & \\
\hline \multirow[t]{2}{*}{ Mandibular overjet } & 0 & $233(64.19)$ & $130(35.81)$ & 0.6833 & $190(65.07)$ & $102(34.93)$ & 0.0742 \\
\hline & 1 & $5(83.33)$ & $1(16.67)$ & & $6(100.00)$ & $0(0.00)$ & \\
\hline \multirow[t]{2}{*}{ Molar relationship } & 0 & $127(65.46)$ & $67(34.54)$ & 0.4858 & $115(66.86)$ & $57(33.14)$ & 0.6435 \\
\hline & 1 & $111(63.43)$ & $64(36.57)$ & & 81 (27.18) & $45(35.71)$ & \\
\hline \multirow[t]{2}{*}{ Gender } & 1 & $115(63.19)$ & $67(36.81)$ & 0.6034 & $80(60.15)$ & $53(39.85)$ & 0.0663 \\
\hline & 2 & $123(65.78)$ & $64(34.22)$ & & $116(70.30)$ & $49(29.70)$ & \\
\hline
\end{tabular}

Table 5. Stepwise logistic regression for 12-year-old adolescents.

\begin{tabular}{|c|c|c|c|c|c|}
\hline \multirow{2}{*}{$\begin{array}{l}\text { Independent } \\
\text { variables }\end{array}$} & \multicolumn{2}{|c|}{$\begin{array}{l}\text { Dependent variable speech } \\
\text { capability (bad, regular) }\end{array}$} & \multirow[b]{2}{*}{ OR } & \multirow[b]{2}{*}{$95 \% \mathrm{Cl}$} & \multirow[b]{2}{*}{$p$} \\
\hline & $n$ & $\%$ & & & \\
\hline \multicolumn{6}{|l|}{ M issing teeth } \\
\hline absence & 70 & 19.77 & 1.000 & $0.984-8.33$ & 0.044 \\
\hline presence & 6 & 40.00 & 2.865 & & \\
\hline \multicolumn{6}{|l|}{ Openbite } \\
\hline absence & 70 & 19.77 & 1.000 & $0.984-8.33$ & 0.0578 \\
\hline presence & 6 & 40.00 & 2.865 & & \\
\hline
\end{tabular}

Table 6. Stepwise logistic regression for 15-year-old adolescents.

\begin{tabular}{|c|c|c|c|c|c|}
\hline \multirow{2}{*}{$\begin{array}{l}\text { Independent } \\
\text { variables }\end{array}$} & \multicolumn{2}{|c|}{$\begin{array}{c}\text { Dependent variable speech } \\
\text { capability (bad, regular) }\end{array}$} & \multirow[b]{2}{*}{ OR } & \multirow[b]{2}{*}{$95 \% \mathrm{Cl}$} & \multirow[b]{2}{*}{$p$} \\
\hline & $\mathrm{n}$ & $\%$ & & & \\
\hline \multicolumn{6}{|l|}{ M andibular overjet } \\
\hline presence & 3 & 50.00 & 4.016 & & \\
\hline Molar relationship & & & & $1.002-2.754$ & 0.0481 \\
\hline absence & 42 & 24.42 & 1.000 & & \\
\hline presence & 44 & 34.92 & 1.661 & & \\
\hline
\end{tabular}


Aderinokun ${ }^{11}$. The statistical association between malocclusion and speech capability verified in this study does not support the findings of ShueTe Yeh et al ${ }^{35}$.

The analyses revealed (Table 4) an association between self-perception relating to "report of pain" and malocclusion, expressed by mandibular irregularity, which seems to confirm the interaction between functional aspects of occlusion and pain $(p<0.01)$. Thus, DAl scores could besignificantly associated with perception of need for treatment ${ }^{36}$.

Theanswersto thequestionnaireindicated that the adolescents in the sample reported pleasant esthetics as an important factor for psychosocial well being. In general, this study showed that orthodontic treatment is accepted as an important part of thehealth service, especially due to the psychological impact of malocclusion on self-esteem. These findings highlight the importance of introducing a perceptual measure of the esthetic impact of malocclusion, in addition to measuring normative orthodontic treatment need.

Since the DAI has been accepted by theW $\mathrm{HO}$, more clinic-based studies (demand populations)

\section{Collaborations}

SHC Sales-Peres participated in the theoretical design, construction methodology, writing and research, as well as the review the final text; $S$ Goya participated in theresearch; KL Cortellazzi and GM B Ambrosiano participated in the statistical analysis; M C M eneghim and AC Pereira participated in the review the final text.

\section{Acknowledgements}

The authors would like to gratefully acknowledge to all pupils and staff of schools that took part in the study. should beencouraged across theglobe. This could be helpful in assessing the severity of malocclusions being treated in several parts of the world, as this is different from epidemiological reports, at least for the purposes of comparison ${ }^{25}$.

The malocclusion perception measured by theDAI was associated with threedependent variables (speech capability, chewing capability and report of pain), which could suggest that in future studies, there may be value in pursuing further refinement of ways to measure these traits, as these may be important dimensions of oral health perceptions, and potential targets for interventions with theaim of improving use of and access to care

\section{Conclusions}

The impact of malocclusion on adolescents' lives was confirmed in this study. Speech and chewing capability were associated with orthodontic deviations, which should be taken into consideration in oral health planning, to identify risk groups and improve community health services.

\section{Referências}

1. Albino JEN, Laurence SD, Tedesco LA. Psychological and social effects of treatment. J Behav Med 1994; 17(1):81-98.

2. Pogrel MA. What are normal esthetic values? J Oral M axillofac Surg 1991; 49(9):963-969.

3. Flores-Mir C, Silva E, Barriga MI, Lagrave M O, Major PW. Lay person's perception of smile aesthetics in dental and facial views. J Orthodont 2004; 31(3):204-209.

4. Gosney MBE. An investigation into some of the factors influencing the desire for orthodontic treatment. Brit J Orthodont 1986; 13(2):87-94.

5. Birkeland K, Katle A, Lovgreen S, Boe OE, Wisth PJ. A longitudinal study among 11- and 15-yearolds and their parents on factors influencing the decision about orthodontic treatment. J Orofacial Orthop 1999; 60(5):292-307.

6. Jenny J. A social perspective of dentofacial esthetics and orthognathic surgery. Angle Orthod 1975; 54(1):18-35.

7. Baldwin DC. Appearance and aesthetic in oral health. Community Dent Oral Epidemiol 1980; $8(5): 244-256$

8. Shaw WC. The influence of children's dentofacial appearance on their social attractiveness as judged by peers and lay adults. Am J Orthod 1980; 79(4):399415. 
9. Ansai $T$, M iyazaki $H$, Katoh $Y$, Yamashita $Y$, Takehara T, Jenny J, Cons NC. Prevalence of malocclusion in high school students in Japan according to the dental Aesthetic Index. Community Dent Oral Epidemiol 1993; 21(5):303-305.

10. Estioko LJ, Wright FAC, Morgan M V. Orthodontic treatment need of secondary school children in Heidelberg, Victoria: an epidemiological study using the DAI. Community Dent Health 1994; 11(3): 147-151.

11. Onyeaso $\mathrm{CO}$, Aderinokun GA. The relationship between dental aesthetic index (DAI) andperceptions of aesthetics, function and speech amongst secondary school children in Ibadan, Nigeria. Int J Paediatr Dent 2003; 13(5):336-341.

12. World Health Organization (WHO). International Collaboration Study of Oral Health Outcomes (ICSII), Document 2 - Oral Data Collection and Examination Criteria. Geneva: WH O; 1989.

13. World Health Organization (WHO). Oral Health Surveys: Basic methods. $4^{\text {th }}$ ed. Geneva: WHO; 1997.

14. Espeland LU, Ivarsson K, Stenvik A, Alstad TA. Perception of malocclusion in 11-year-old children: a comparison between personal and parental awareness. Eur J Orthod 1992; 14(5):350-358.

15. Onyeaso CO, Sanu OO. Psychosocial implications of malocclusion among 12-18 year old secondary school children in Ibadan. Odontostomatol Trop 2005; 28(109):39-48.

16. Lewit DW, Virolainen K. Conformity and independence in adolescents' motivation for orthodontic treatment. Child Dev 1968; 39(4):1189-1200.

17. Onyeaso CO. Orthodontic Treatment Complexity and Need in a Group of Nigerian Patients: The Relationship between the Dental Aesthetic Index (DAI) and the Index of Complexity, Outcome, and Need (ICON). J Contemp Dent Pract 2007; 8(3):37-44.

18. Landis JR, Koch GG. The measurement of observer agreement for categorical data. Biometrics 1977; 33(1):159-174.

19. Lucas SD, Portela MC, M endonça LL. Variations in tooth decay rates among children 5 and 12 years old in M inas Gerais, Brazil. Cad Saude Publica 2005; 21(1):55-63.

20. Tagliaferro EPS, Pereira AC, M eneghim MC, Ambrosano GM B. Assessment of dental caries predictors in a seven-year longitudinal study. J Publ Health Dent 2006; 66(3):169-173.

21. SAS User's Guide: Statistics. Version 8.2. Cary (NY): SAS Institute Inc.; 2001.

22. Botazzo C. Sobre a bucalidade: notas para a pesquisa e contribuição ao debate. Cien Saude Colet 2006; 11(1):7-17.

23. Horowitz HS, Vohen LK, Doyle J. Occlusal relations in children born and reared in an optimally fluoridated community. (IV) Clinical and socio-psychological findings. Angle Orthod 1971; 41(3):189-201.

24. Jenkins PM, Feldman BS, Stirrups DR. The effect of social class and dental features on referrals for orthodontic advice and treatment. $\mathrm{Br} J$ Orthod 1984; $11(4): 185-188$.
25. Onyeaso CO, BeGole EA. Orthodontic Treatment Need in an Accredited Graduate Orthodontic Center in North America: A Pilot Study. J Contemp Dent Pract 2006; 7(2):1-5.

26. Cons NC, Jenny J, Kohout FJ. DAl: the Dental Aesthetic Index. Iowa City: College of Dentistry University of Iowa; 1986.

27. Katoh Y, Ansai T, Kitakyushu TT, Fukuoka YY, Niigata HM, Jenny J, Cons NC. A comparison of DAI scores and characteristics of occlusal traits in three ethnic groups of Asian origin. Int Dent J 1998; 48(4): 405-411.

28. Jenny J, Cons NC, Kohout FJ, Jakobson J. Differences in need for orthodontic treatment between native Americans and the general population based on DAl scores. J Public Health Dent 1991; 51(4):234-238.

29. Brasil. M inistério da Saúde (MS). Secretaria de políticas de Saúde. Departamento de Atenção Básica. Área Técnica de Saúde Bucal. Projeto SB Brasil: condições de saúde bucal da população brasileira. Resultados principais. Brasília: M inistério da Saúde; 2004.

30. Frazão $P, N$ arvai $P C$, Latorre MRDO, Castellanos RA. Prevalência de oclusopatia na dentição decídua e permanente de crianças na cidade de São Paulo, Brasil, 1996. Cad Saude Publica 2002; 18(5):1197-1205.

31. M arques LS, Barbosa CC, Ramos-Jorge ML, Pordeus IA, Paiva SM. Prevalência da maloclusão e necessidade de tratamento ortodôntico em escolares de 10 a 14 anos de idade em Belo Horizonte, $M$ inas Gerais, Brasil: enfoque psicossocial. Cad Saude Publica 2005; 21(4):1099-1106.

32. Alsaker F, Olweus D. Global self-evaluations and perceived instability of self in early adolescence: a cohort longitudinal study. Scand J Psychol 1993; $34(1): 47-63$.

33. Korabik K. Self-concept changes during orthodontic treatment. J Appl Soc Psychol 1994; 24(11):1022-1034.

34. Varela M, Garcia-Camba JE. Impact of orthodontics on psychologic profile of adults patients: a prospective study. Am J Orthod D entofacial Orthop 1995; 108(2):142-148.

35. Shue-Te Yeh M, Koochek AR, Vlaskalic V, Boyd R, Richmond $\mathrm{S}$. The relationship of 2 professional occlusal indexes with patients' perceptions of aesthetics, function, speech, and orthodontic treatment need. Am J Orthod Dentofacial Orthop 2000; $118(4): 421-428$.

36. Jenny J, Cons NC. Establishing malocclusion severity levels on The Dental Aesthetic Index (DAI) scale. Aust Dent J 1996; 41(1):43-46.

Artigo apresentado em 08/03/2010

Aprovado em 19/06/2010

Versão final apresentada em 30/06/2010 